\title{
Response to Philippe Besnard*
}

* In J. Clark et al. (eds), Robert K. Merton. Consensus and controversy, London-New York-Philadelphia, Falmer Press, 1990, 255-256.

Marco Orrù

\section{(2) OpenEdition}

Journals

Electronic version

URL: http://journals.openedition.org/ress/451

DOI: $10.4000 /$ ress. 451

ISSN: $1663-4446$

Publisher

Librairie Droz

Printed version

Date of publication: 1 March 2004

Number of pages: $380-382$

ISBN: 2-600-00941-8

ISSN: 0048-8046

\section{Electronic reference}

Marco Orrù, « Response to Philippe Besnard* », Revue européenne des sciences sociales [Online], XLII-129 | 2004, Online since 09 November 2009, connection on 19 April 2019. URL : http://

journals.openedition.org/ress/451; DOI : 10.4000/ress.451 


\section{RÉFÉRENCES BIBLIOGRAPHIQUES}

Baudelot Ch., Establet R., 1984, Durkheim et le suicide, Paris, Presses universitaires de France.

Besnard Ph., 1973, «Durkheim et les femmes ou le Suicide inachevé», Revue française de sociologie, 14 (1), 27-61.

- 1976, «Anti- ou anté-durkheimisme? Contribution au débat sur les statistiques officielles du suicide », Revue française de sociologie, 17(2), 313-341.

- 1984, «Modes d'emploi du Suicide: intégration et régulation dans la théorie durkheimienne», L'Année sociologique, 34, 127-163.

- $\quad$ 1985, L'anomie. Destin d'un concept. Thèse de doctorat ès lettres, Université Paris X.

Durkheim E., 1897. Le suicide. Étude de sociologie, Paris, Alcan.

- 1909, Intervention dans un débat sur «Mariage et divorce», Libres entretiens (Union pour la vérité), $5^{\mathrm{c}}$ s., 258-293.

Halbwachs M., 1930, Les causes du suicide, Paris, Alcan.

Gove W. R., 1973, «Sex, marital status, and mortality », American journal of sociology, 79 (1), 45-67.

Kobrin F. E., Heoderahot G. E., 1977, «Do family ties reduce mortality? Evidence from the United States, 1966-1968», Journal of marriage and the family, 39(4), 737-745.

Mergenhagen P. M., Lea R. A., Gove W. R., 1985, «Till death do us part: recent changes in the relationship between marital status and mortality», Sociology and social research, 70 (1), 53-56.

Vallin J., Nizard A., 1977, «La mortalité par état matrimonial. Mariage sélection ou mariage protection », Population, 32, 95-123.

\section{Marco ORRÙ}

\section{RESPONSE TO PHILIPPE BESNARD*}

Scarcely a Century after sociology's inception as an academic discipline sociologists tacitly agree (perhaps reluctantly) that it is very difficult, if not impossible, to analyze and to interpret sociological theories in universally accepted, univocal ways. Much of today's sociology is still preoccupied with settling conflicting claims about the legacy of the founders of our discipline, and no final verdict is in sight. The present book on Robert Merton's sociology rests on the assumption of disagreement over the legacy of his work. It should not surprise the reader, then, that Philippe Besnard and myself should have come to such contrasting evaluations of Merton's theory of anomie.

While disagreement exists, it need not be accepted as inevitable, and the present response to Besnard's 'Merton in Search of Anomie' will scrutinize some of that paper's claims and supporting arguments. Besnard's paper is very detailed in its exegesis of Merton's texts on anomie, but for economy of space I will not be able to take up the finer points of his discussion; instead, I will limit my considerations to the general assumptions on which Besnard's analysis rests, and on the consequent claims he makes regarding Merton's theory. Specifically, I will scruti-

* In J. Clark et al. (eds), Robert K. Merton. Consensus and controversy, London-New York-Philadelphia, Falmer Press, 1990, 255-256. 
nize Besnard's assertions that Merton's writings on anomie do not constitute a theory and do not actually relate to anomie. Besnard's double contention rests on four claims : that Merton's discussions on anomie (1) utilize ambiguous concepts; (2) do not link the propositions advanced; (3) provide an uncertain status of the concept [of anomie]; and (4) contribute nothing to Merton's overall sociological purpose.

As I read Besnard's paper and much of his earlier research on anomie, there are two major assumptions which underlie his work. Besnard assumes that we can distinguish unequivocally between those sociological writings which add up to a theory and those which do not; he also assumes that we can clearly separate ambiguous and unambiguous (or true and false) sociological concepts. Certainly there are cases in which a clear assessment can be made regarding the status of some theories and concepts; but these will be likely to characterize the least significant contributions to sociology. I argue, however, that the more significant a theoretical or conceptual elaboration, the more likely that it will be a target of scholarly disagreement. The true sign of theoretically and conceptually significant contributions in sociology is that these contributions influenced and still influence research in the field despite the barrage of criticism to which they have been subjected. Besnard's own work on anomie, which to a large extent evaluates the career of this sociological concept negatively, is an unwitting additional testimony to that concept's significance today.

Absolute theoretical consistency and conceptual adequacy are perhaps desirable, but who meets these criteria? Not Durkheim, not Marx, not Weber, no Merton, and alas, not Besnard. But should one throw out the baby with the bath water because theoretical and conceptual perfection has not been achieved Besnard's verdict regarding Merton's writings on anomie is a resounding yes! Yet even within such negative assessment, Besnard sees some redeeming qualities in Merton's theory - why would he otherwise bother to correct Merton's 'incoherent and incomplete typology' by providing his own version of a complete set of mode of adaptation? There is, then, even for Besnard, room for optimism and for improvement in Merton's theoretical elaboration.

I find still more disturbing Besnard's refusal to see Merton's as a theory $o$ anomie. For Besnard, Merton's writings have nothing to do with anomie because Merton is never clear about what he means by anomie - because his use of the concept is uncertain and ambiguous. It will be of little consolation for Merton to learn that by Besnard's standards Durkheim's concept of anomie does not fare much better - it too is insufficiently elaborated, and in need of clarification. Again, Besnard sets standards for conceptual adequacy which are patently unrealistic; but more importantly, Besnard fails to acknowledge that, perhaps, the ambiguity an uncertainty he so much criticizes are constant features of sociological theorizing. He ignores the possibility that sociological ambiguity might simply reflect the ambiguity which characterizes social life. Yes, the meaning of anomie shifted from Durkheim to Merton, it shifted within Durkheim's and perhaps within Merton's own theory; but does this mean that the concept is useless? In the name of logical consistency Besnard takes leave from reality: he wants to find the 'true nature' of anomie when there is no such thing in the real world. Durkheim's and Merton's concepts of anomie are vague approximations of some social phenomenon, but just as it is impossible to grasp the true, ultimate nature of a 
social phenomenon, it is impossible to grasp the true, ultimate nature of the concept which attempts to describe it. In the end we can choose to make the most out of our working concepts and tentative hypotheses, or we can choose instead to recite the requiem aeternam of most sociological theories and concepts. Besnard seems to have made the latter choice.

\section{Philippe BESNARD}

\section{RESPONSE TO MARCO ORRÜ*}

Marco Orrù had an extremely difficult task: to write in praise of the Mertonian theory of anomie. He has acquitted himself as well as he can, but in doing so he is obliged to avoid the simple questions which I have asked of this 'theory', questions which Orrù knows, since he makes reference both to my book and to an earlier article of mine. These questions are, for example: what is the meaning of the word 'anomie' in Merton's writings? Why has Merton never discussed the Durkheimian concept of anomie, while letting us believe that his own analyses both continue and enlarge upon those of Durkheim? What is the meaning of the famous typology of modes of individual adaptation and how coherent is it? To what do these adaptations adapt: is it to an anomic culture or not? Finally, what purpose is served by the term 'anomie' apart from that of a convenient and decorative label? Marco Orrù has taken good care not to take up the challenge that I have thrown down: to define what Merton means by the term 'anomie'. In fact no one has so far succeeded in this: an answer is still awaited.

Instead of conducting a close textual analysis Orrù prefers to adopt a global approach to Merton's writings and to defend them by arguing that it is not necessary to know which of Durkheim and Merton is the 'winner'. Contrary to what he suggests, I have neyer thought that 'straying from the Durkbeimian path would automatically make Merton's theory illegitimate'. In fact I have written exactly the opposite. Everyone is free to define a word as they understand it, on condition that they say in which sense they are using it. Moreover, I am just as critical of the Durkheimian conceptualization as I am of Merton's. Finally, the core of my critique of Merton's essay 'Social Structure and Anomie' is not concerned with this question, even though I $d o$ believe it was important to have demonstrated that the Mertonian concept of anomie - to the extent that one can identify its content and such as it has been generally understood - is opposed to that of Durkheim on all points.

This opposition has nothing to do with the differences outlined by Orrù. Like other commentators, Orrù affirms that Merton locates the origin of human desires in society, while for Durkheim they are supposed to have a biological origin. I must admit to some difficulty in understanding how such a reading of Durkbeim

* $\quad$ Ibid., 256-257. 